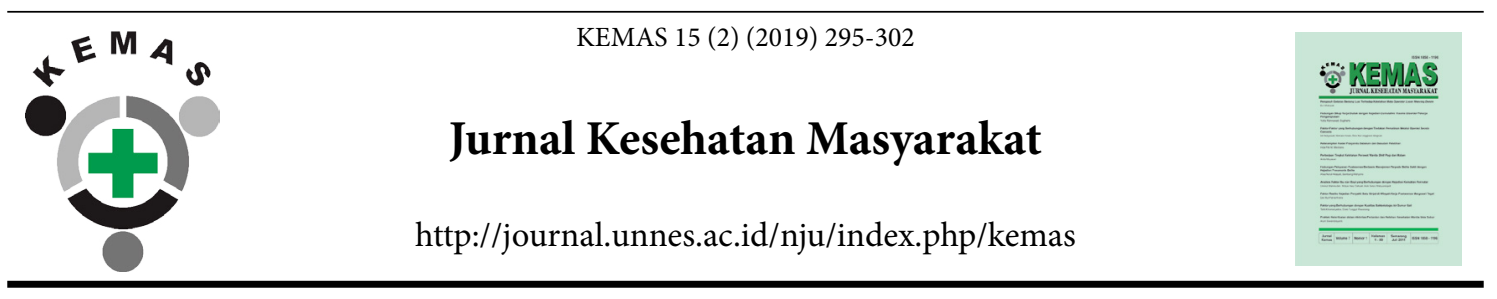

\title{
Risk Factors of Cognitive Impairment Post Ischemic Stroke
}

\author{
Rr Rizqi Saphira Nurani ${ }^{1}$, Santi Martini ${ }^{\circledR 凶}$, Fanni Marzela ${ }^{1}$ \\ ${ }^{1}$ Fakultas Kesehatan Masyarakat, Universitas Airlangga \\ ${ }^{2}$ Departemen Epidemiologi, Fakultas Kesehatan Masyarakat Universitas Airlangga
}

\section{Article Info \\ Article History: \\ Submitted November 2018 \\ Accepted February 2019 \\ Published November 2019 \\ Keywords: \\ ischemic stroke, cogni- \\ tive impairment, risk \\ factor, demographic \\ factors, vascular factors \\ DOI \\ https://doi.org/10.15294/ \\ kemas.v15i2.16845}

\begin{abstract}
The aim of this research was to analyze the risk factors of cognitive impairment post-ischemic stroke. This research was case control design, consisted of 38 cases and 38 control. Mini Mental State Examination (MMSE) and the Pittsburg Sleep Quality Index (PSQI) were tools to obtain data. Independent variables were age, gender, educational level, history of hypertension, exposure to cigarette smoke, medication compliance, and sleep pattern. The risk factors were age $(\mathrm{OR}=3,43 ; 95 \% \mathrm{CI}=1,08<\mathrm{OR}<10,89)$, sex $(\mathrm{OR}=2,67$; $95 \% \mathrm{CI}=1.05<\mathrm{OR}<6,83)$, educational level $(\mathrm{OR}=4,17 ; 95 \% \mathrm{CI}=1,60<\mathrm{OR}<10,86)$, history of hypertension $(\mathrm{OR}=1,60 ; 95 \% \mathrm{CI}=0,62<\mathrm{OR}<4,17)$, exposure to cigarette smoke $(\mathrm{OR}=1,24 ; 95 \% \mathrm{CI}=0,50<\mathrm{OR}<3,04)$, medication compliance $(\mathrm{OR}=6,59 ; 95 \% \mathrm{CI}=$ $2,23<\mathrm{OR}<19,43)$, and sleep pattern $(\mathrm{OR}=8,125 ; 95 \% \mathrm{CI}=2,88<\mathrm{OR}<22,93)$. It is suggested for ischemic stroke's patient to maintain medication compliance and sleep pattern.
\end{abstract}

\section{Introduction}

Stroke is a disruption of the brain in local and / or global nerve function, appearing suddenly, progressively, and quickly. Stroke causes neurological disorders that lead to symptoms including paralysis of the face, unclear and influent speech, and others (Kemenkes RI, 2013).

The prevalence of stroke in Indonesia is 12.1 per 1000 population. It is increased according to Riskesdas in 2007 which was $8.3 \%$. Stroke is the leading cause of death in almost all hospitals in Indonesia which is $14.5 \%$. The prevalence of stroke based on the diagnosis of health workers and symptoms was highest in South Sulawesi (17.9\%), DI Yogyakarta (16.9\%), Central Sulawesi (16.6\%), followed by East Java at 16 per mile (Kemenkes RI, 2013) . Changes in people's lifestyle is one of the causes of an increase in the number of stroke patients from year to year (Irdawati, 2012).
Stroke can cause disorder of both physically and psychosocially. One of the problems caused by stroke is cognitive impairment in the patients. Percentage of cognitive impairment in stroke patients is 5075\% (Rahayu et al., 2014). Cognitive disorders caused by stroke include attention, orientation, memory, and way of thinking (Batubara \& Putri, 2018; Murtiyani et al., 2017).

Cognitive function is intended to show a person's ability to learn, receive, and manage information from the surrounding environment. Brain damage is a factor that affect cognitive function, thus giving rise to manifestations of cognitive disorder. Damage to the left and right hemispheres gives a different form of symptoms because there has been a process of lateralization of certain functions to one hemisphere (cerebral dominance). Damage to the left hemisphere will cause impaired ability to speak, read, write, count, verbal memory and 
skilled motor movements. Damage to the right hemisphere will cause impaired visuospatial function (perception), visuomotor, neglecta, visual memory, and motor coordination (Harsono, 2007).

Cognitive function disorder is a disorder of sublime brain function in the form of impaired orientation, attention, concentration, memory and language as well as intellectual function that is shown by the presence of disturbances in counting, language, semantic memory (words) and problem solving. Stroke increases the risk for cognitive decline as much as 3 times (Ratnasari, 2010).

In the United States, it is estimated that there are still around 500,000 new and recurrent stroke cases each year and there are currently around 4 million post-stroke people who experience neuropsychological symptoms (Suwantara, 2004). The risk of impaired cognitive function in stroke patients increases with age and reaches a peak at the age of 75 years (Demarin et al., 2009).

Post stroke cognitive disorders are associated with long-term survival that leads to the quality of patients life (Health-related Quality of Life), which is the result of cognitive impairment and other sublime functions that can interfere with daily life activities and often cause patient dependence with others, as well as reducing work productivity (Rahayu et al., 2014; Rahman et al., 2017) which consist of 6 items related to assessment of cognitive function for stroke patients. The data was analyzed by univariate analysis and bivariate analysis by using Fisher test. From the statistic data, $\rho$ value $(0,02)$.

Several studies conducted homeland and abroad have proven that stroke can cause cognitive dysfunction. It can be checked by MMSE (mini mental state examination) test and the examination results show a decrease in one or more dominant values (Yudawijaya et al., 2011).

Methods

This research is an observational analytic study using a case control design. The aspects studied were risk factors of age, sex, level of education, history of hypertension, exposure to cigarette smoke, sleep patterns, and medication compliance to cognitive disorders in post- ischemic stroke.

The research was conducted at Surabaya

Hajj Hospital. The case population was cognitive impaired patients after ischemic stroke after one to two years. While the control population in this study were patients without cognitive impairment after ischemic stroke after one to two years. The sample size in the case population was 38 ischemic stroke patients. The control sample was 38 ischemic stroke patients. The sampling method in this research is non probability sampling with accidental sampling technique.

The data collection instrument used respondents data questionnaire, Mini Mental State Examination (MMSE) questionnaire to measure cognitive function, and Pittsburg Sleep Quality Index (PSQI) questionnaire to measure sleep quality and patterns.

The data analysis technique used in this research was Odds Ratio (OR) calculation in Epi Info version 7.2.1.0 with a significance level of $95 \%$ Confidence Interval to see the risk magnitude of risk factors for cognitive impairment after ischemic stroke.

\section{Result and Discussion}

Research subjects aged $>55$ years were 58 people $(76.32 \%)$ and 18 people $(23.68 \%)$ aged $\leq 55$ years. The proportion of stroke patients aged $>55$ years who experienced cognitive impairment was $56.90 \%$ and those without cognitive impairment was $43.10 \%$. The proportion of ischemic stroke patients aged $\leq$ 55 years who experienced cognitive impairment was $27.78 \%$ and stroke patients aged $\leq 55$ years who did not experience cognitive impairment was $72.22 \%$. The calculation results of the risk obtained OR value of 3.43 with $95 \% \mathrm{CI}=$ $1.08<\mathrm{OR}<10.89$. This indicates that the $\mathrm{OR}$ is significant so that ischemic stroke patients aged $>55$ years are at risk of cognitive impairment 3.43 times greater than patients ischemic stroke aged $\leq 55$ years (Table 1 ).

Female subjects were 33 people $(43.42 \%)$ and as many as 43 people (56.58\%) were male. The proportion of female stroke patients who experienced cognitive impairment was $63.64 \%$ and those who did not experience cognitive impairment was $36.36 \%$. The proportion of male stroke patients who experienced cognitive impairment was $39.54 \%$, and who did not 
Table 1. Demographic Characteristics of Ischemic Stroke Patients

\begin{tabular}{|c|c|c|c|c|}
\hline \multirow[t]{2}{*}{ Variable } & \multicolumn{2}{|c|}{ Cognitive Impairment } & \multirow[t]{2}{*}{ Total } & \multirow{2}{*}{$\begin{array}{l}\text { OR } \\
95 \% \text { CI }\end{array}$} \\
\hline & $\begin{array}{l}\text { Yes } \\
(\mathrm{n}=38)\end{array}$ & $\begin{array}{l}\text { No } \\
(\mathrm{n}=38)\end{array}$ & & \\
\hline Age & & & & $\mathrm{OR}=3,43$ \\
\hline $41-55$ years & 5 & 13 & 18 & $1,08<\mathrm{OR}<10,89$ \\
\hline $56-78$ years & 33 & 25 & 58 & \\
\hline Gender & & & & $\mathrm{OR}=2,67$ \\
\hline Female & 21 & 12 & 33 & $1,05<\mathrm{OR}<6,83$ \\
\hline Male & 17 & 26 & 43 & \\
\hline Education Level & & & & $\mathrm{OR}=4,17$ \\
\hline $\begin{array}{l}\text { Elementary }- \text { Junior } \\
\text { High }\end{array}$ & 26 & 13 & 39 & $1,60<\mathrm{OR}<10,86$ \\
\hline Senior High and above & 12 & 25 & 37 & \\
\hline
\end{tabular}

source : Primary Data

experience cognitive impairment was $60.46 \%$. The calculation results of the risk obtained OR value of 2.67 with $95 \% \mathrm{CI}=1.05<\mathrm{OR}<6.83$. This indicates that the OR is significant so that female ischemic stroke patients who are at risk of cognitive impairment 2.67 greater than male ischemic stroke patients (Table 1).

As many as 39 people $(51.32 \%)$ of the research subjects completed education at the elementary level (elementary-junior high school) and 37 people $(48.68 \%)$ completed education at the advanced level (high school and above). The proportion of stroke patients who completed primary education who experienced cognitive impairment was $66.67 \%$ and those without cognitive impairment was $33.33 \%$. The proportion of stroke patients who completed advanced education who experienced cognitive impairment was $32.43 \%$ and those without cognitive impairment was $67.57 \%$. The calculation results of the risk obtained OR value of 4.17 with $95 \% \mathrm{CI}=1.60<\mathrm{OR}<10.86$. This indicates that the OR is significant so that ischemic stroke patients with primary education level were at risk of experiencing cognitive impairment 4.17 times greater than those with higher level of education (Table 1).

From 76 research subjects, 50 people (65.79\%) had a history of hypertension and 26 people $(34.21 \%)$ did not have a history of hypertension. The proportion of stroke patients who have a history of hypertension who experience cognitive impairment was $54 \%$ and those without cognitive impairment was $46 \%$. The proportion of stroke patients who did not have a history of hypertension who experienced cognitive impairment was $42 \%$ and those without cognitive impairment was $58 \%$. The calculation results of the risk obtained OR value of 1.60 with $95 \% \mathrm{CI}=0.62<\mathrm{OR}<4.17$. This indicates that OR is not significant so that a history of hypertension is not related with cognitive impairment after ischemic stroke and hypertension history is not a risk factor for cognitive impairment after ischemic stroke (Table 2).

Research subjects exposed to cigarette smoke were 40 people (52.63\%) and those not exposed to cigarette smoke were 53 people (47.37\%). The proportion of stroke patients exposed to cigarette smoke who experienced cognitive impairment was $52.5 \%$ and those without cognitive impairment was $47.5 \%$. The proportion of stroke patients who were not exposed to cigarette smoke who experienced cognitive impairment was $47.22 \%$ and those who did not experience cognitive impairment was $52.78 \%$. The calculation results of the risk obtained OR value of 1.24 with $95 \% \mathrm{CI}=$ $0.50<\mathrm{OR}<3.04$. This indicates that $\mathrm{OR}$ is not significant so that exposure to cigarette smoke is not associated with cognitive impairment after 
Rr Rizqi Saphira Nurani, Santi Martini, \& Fanni Marzela / Risk Factors of Cognitive Impairment Post Ischemic Stroke

Table 2. Risk's Value of Cognitive Impairment after Ischemic Stroke Based on State of Hypertension

\begin{tabular}{lllll}
\hline Hypertension History & \multicolumn{2}{l}{ Cognitive Impairment } & Total & $\begin{array}{l}\text { OR } \\
\text { 95 CI }\end{array}$ \\
\cline { 2 - 3 } & $\begin{array}{l}\text { Yes } \\
(\mathbf{n = 3 8})\end{array}$ & $\begin{array}{l}\mathbf{N} \\
\mathbf{( n = 3 8 )}\end{array}$ & & \\
\hline Have Hypertension History & 27 & 23 & 50 & OR $=1,60$ \\
No Hypertension History & 11 & 15 & 26 & $0,62<\mathrm{OR}<4,17$ \\
\hline
\end{tabular}

Source : Primary Data

Table 3. Risk's Value of Cognitive Impairment after Ischemic Stroke Based on Cigarette's Smoke Exposure

\begin{tabular}{|c|c|c|c|c|}
\hline \multirow{2}{*}{$\begin{array}{l}\text { Cigarette } \\
\text { Exposure }\end{array}$} & \multicolumn{2}{|c|}{ Cognitive Impairment } & \multirow[t]{2}{*}{ Total } & \multirow{2}{*}{$\begin{array}{l}\text { OR } \\
95 \% \text { CI }\end{array}$} \\
\hline & $\begin{array}{l}\text { Yes } \\
(n=38)\end{array}$ & $\begin{array}{l}\text { No } \\
(n=38)\end{array}$ & & \\
\hline Exposed & 21 & 19 & 40 & $\mathrm{OR}=1,24$ \\
\hline Not exposed & 17 & 19 & 36 & $0,50<\mathrm{OR}<3,04$ \\
\hline
\end{tabular}

Source : Primary Data

Table 4. Risk's Value of Cognitive Impairment after Ischemic Stroke Based on Sleep Pattern

\begin{tabular}{lllll}
\hline Sleep Pattern & \multicolumn{2}{l}{ Cognitive Impairment } & Total & $\begin{array}{l}\text { OR } \\
95 \% \mathrm{CI}\end{array}$ \\
\cline { 2 - 3 } & $\begin{array}{l}\text { Yes } \\
(\mathrm{n}=38)\end{array}$ & $\begin{array}{l}\text { No } \\
(\mathrm{n}=38)\end{array}$ & & \\
\hline Abnormal & 30 & 12 & 42 & OR $=8,125$ \\
Normal & 8 & 26 & 34 & $2,88<$ OR $<22,93$ \\
\hline
\end{tabular}

Source : Primary Data

ischemic stroke and cigarette smoke exposure is not a risk factor of cognitive impairment after ischemic stroke (Table 3).

Research subjects with normal sleep pattern were 34 people $(44.74 \%)$ and who have abnormal sleep pattern were 42 people (55.26\%). The proportion of stroke patients with abnormal sleep patterns who experienced cognitive impairment was $71.43 \%$ and those without cognitive impairment was $28.57 \%$. The proportion of stroke patients with normal sleep patterns who experienced cognitive impairment was $23.53 \%$ and who do not experience cognitive impairment was $76.47 \%$. The results of risk analysis obtained an OR value of 8.125 with $95 \% \mathrm{CI}=2.88<\mathrm{OR}<22.93$. This indicates that OR is significant so that ischemic stroke patients who have abnormal sleep patterns are at risk of experiencing cognitive impairment 8.125 times greater than those who have normal sleep patterns (Table 4).

Research subjects who comply to medication were 49 people $(64.47 \%)$ and who did not comply to medication were 27 people $(35.53 \%)$. The proportion of stroke patients who were not compliant to take medication who experience cognitive impairment was $77.78 \%$ and those without cognitive impairment was $22.22 \%$. The proportion of stroke patient who comply to medication that had cognitive impairment was $34.70 \%$ and those without cognitive impairment was $65.31 \%$. The results of risk analysis obtained an OR value of 6.59 with $95 \% \mathrm{CI}=2.23<\mathrm{OR}<19.43$. This indicates that the OR is significant so it can be concluded that ischemic stroke patients who are not compliant to take medication at risk of cognitive impairment 6.59 times greater than ischemic stroke patients who comply to medication (Table 5).

Age is a risk factor for cognitive impairment after ischemic stroke according to reported research (Knopman et al., 2011; Gorelick et al., 2015; Kabi et al., 2015; Al-Hashel 
Table 5. Risk's Value of Cognitive Impairment after Ischemic Stroke Based on Medication Compliance

\begin{tabular}{lllll}
\hline Medical Compliance & \multicolumn{2}{l}{ Cognitive Impairment } & Total & $\begin{array}{l}\text { OR } \\
\text { 9. }\end{array}$ \\
\cline { 2 - 3 } & $\begin{array}{l}\text { Yes } \\
(\mathbf{n = 3 8})\end{array}$ & $\begin{array}{l}\mathbf{N o} \\
(\mathbf{n = 3 8})\end{array}$ & & \\
\hline Comply & 21 & 6 & 27 & OR $=6,59$ \\
Uncomply & 17 & 32 & 49 & $2,23<\mathrm{OR}<19,43$ \\
\hline
\end{tabular}

Source : Primary Data

et al., 2016. Unlike many neurodegenerative causes of cognitive impairment and dementia, vascular damage is preventable. Despite the heterogeneity of vascular cognitive impairment (VCI. The prevalence of cognitive decline after stroke will increase exponentially with increasing age (Sun etal., 2014; Arboix, 2015; Zulkifly et al., 2016) which varies for the difference between the countries, the races, and the diagnostic criteria. The risk of poststroke cognitive impairment is related to both the demographic factors like age, education and occupation and vascular factors. The underlying mechanisms of post-stroke cognitive impairment are not known in detail. However, the neuroanatomical lesions caused by the stroke on strategic areas such as the hippocampus and the white matter lesions (WMLs. A stroke that occurs in someone with an older age can increase the risk of cognitive impairment than in a young age. This can occur due to other cerebrovascular pathology in the old brain that may occur due to a stroke that has ever suffered or a disease other than ischemic stroke (Putri et al., 2017).

Female is more at risk of experiencing cognitive impairment because of the role of endogenous sex hormone levels in cognitive function changes. Low level of estradiol in the body is associated with decreased general cognitive function and verbal memory. Estradiol is thought to be neuroprotective and can limit damage due to oxidative stress and is seen as a protective nerve cell from amyloid toxicity in cognitive impaired patients (Myers, 2008). These results are consistent with the results of research conducted by Knopman et al., (2011).

Education level is a risk factor for cognitive impairment after ischemic stroke.
Higher education levels can increase tolerance for cognitive impairment in stroke patients (Wu et al., 2013; Zulkifly et al., 2016; Putri et al., 2017). The level of education itself is included as a risk factor for conflict because it can affect the expression of cognitive impairment (Sun et al., 2014) which varies for the difference between the countries, the races, and the diagnostic criteria. The risk of post-stroke cognitive impairment is related to both the demographic factors like age, education and occupation and vascular factors. The underlying mechanisms of post-stroke cognitive impairment are not known in detail. However, the neuroanatomical lesions caused by the stroke on strategic areas such as the hippocampus and the white matter lesions (WMLs. According to Hanas et al., 2016), education can improve the ability and strategies to solve problems so as to reduce the incidence of cognitive impairment after stroke.

Exposure to cigarette smoke is not a risk factor for cognitive impairment after ischemic stroke contrary to previous studies (Stroke Association, 2010). The patient's smoking history also does not directly affect cognitive function (Totting et al., 2017). Nicotine in cigarettes will react in the brain 10 seconds after inhaling cigarette smoke. Nicotine binds to nicotinic receptors which facilitate the release of adrenergic neurotransmitters, this process is important in cognitive function, memory, alertness, and decreased appetite (Setiawati, 2013). This might occur because cigarette smoke exposure is one of the risk factors for ischemic stroke, so most of the ischemic stroke patients who were respondents in the research were exposed to cigarette smoke (Wang et al., 2016) CMIs are defined as microscopic regions of ischemia-related cellular death or tissue necrosis, invisible to the naked eye. CMIs 
frequently occur $(16.7 \%-100 \%)$. Stroke and smoking are associated with morbidity because smoking can affect coagulation and can reduce blood flow to the brain and can increase the risk of clot formation which results in the risk of stroke by means of flow retardation or static flow phenomena (Fahrina et al., 2018).

History of hypertension is not a risk factor for cognitive impairment after ischemic stroke, the result of this research is in accordance with previous one (Martini, 2002; Brucki et al.,2012). The result is not in line with one conducted by Arntzen et al., (2010). The process of cognitive impairment in patients with hypertension begins with the occurrence of pathological changes in the blood vessels of the brain. Pathological changes in the brain will cause abnormalities in the brain vessels. Abnormalities and damage to brain vessels will cause an increased risk of cognitive impairment (Birns and Kalra, 2009; Arntzen et al., 2010).

The relationship between sleep disorders and risk factors for vascular disease such as stroke has been well documented but is not widely known. Sleep disorders may contribute to the pathological stroke vascular through direct and indirect mechanisms. The consequence of sleep disorders that are not treated immediately that is cognitive impairment is the slow rehabilitation process of stroke (Hermann and L., 2009). This condition because stroke has a significant impact on psychological wellbeing, stroke patients will usually experience sleep disturbance as one of the impacts caused (Zulkifly et al., 2016).

Medication compliance is a risk factor for cognitive impairment after ischemic stroke (Putra et al., 2016). According to (Glader et al., 2010), compliance to take medication in stroke patients is often poor, $50 \%$ of patients do not continue treatment until two years after a stroke. According to Mellon et al., (2015), taking medication obediently is a secondary prevention of the incidence of cognitive impairment in post-stroke patients. Because in patients who have had a stroke there will be an increased risk of decreased cognitive function, the risk is even greater if compliance to taking medication is low so that the incidence of recurrent stroke occures (Rahayu et al., 2014) which consist of 6 items related to assessment of cognitive function for stroke patients. The data was analyzed by univariate analysis and bivariate analysis by using Fisher test. From the statistic data, $\rho$ value $(0,02)$. Repeated ischemic stroke can result in an increase in the prevalence of cognitive impairment, the condition can result in a state of dementia (Putri, Mutiawati and Mahdani, 2017). Several factors are the reason for noncompliance in the treatment process, namely taking medication, among others in the form of 1) Factors related to the drug itself such as side effects that arise, the number of treatments at the same time, and too long for the treatment received; 2) Factors related to the patient himself such as mental state, financial condition, do not feel any health problems, and lack of knowledge of the benefits to be gained; 3) Factors related to health workers such as communication between health workers and patients is not good and the lack of skills of health workers so that patients do not understand the explanation given; 4) Systemrelated factors such as poor service provided by the insurance system or health insurance (Kurniawati, Ikawati and Gofir, 2015).

\section{Conclusion}

Demographic factors which are risk factors for cognitive impairment after ischemic stroke are age $>55$ years, female gender, level of basic education. Other factors that are at risk of causing cognitive impairment after ischemic stroke are abnormal sleep patterns, and medication non-compliance.

The results of this research indicate that sleep patterns and medication compliance are important factors to be controlled as an effort to prevent one of the post-effect of ischemic stroke, namely cognitive impairment. Therefore it is necessary to take preventive measures in the form of counseling and early detection of cognitive disorders. The results of the research are used as input for the hospital in making poster, leaflet, or pocket book material about the healthy lifestyle for stroke patients to avoid severe cognitive impairment to improve the quality of life of stroke patients.

\section{References}

Al-Hashel, J. Y., Al-Sabah, A., Ahmed, S.F., Al-Enezi, M., Al-Tawheid, N., Mesailekh, Z.A., Eliwa, J., \& Alroughani, R., 2016. Risk Factors, Subtypes, and Outcome of Ischemic Stroke 
in Kuwait: A National Study. Journal of Stroke and Cerebrovascular Diseases. Elsevier Inc., 25(9): 2145-2152.

Arboix, A., 2015. Cardiovascular Risk Factors for Acute Stroke: Risk Profiles in the Different Subtypes of Ischemic Stroke, World Journal of Clinical Cases, 3(5): 418.

Arntzen, K. A., Schirmer, H., Wilsgaard., \& Matheiesen, E.B., 2010. Impact of Cardiovascular Risk Factors on Cognitive Function: The Tromsø Study. European Journal of Neurology, 18(5): 737-743.

Batubara, S. \& Putri, A.C., 2018. Perbedaan Penurunan Fungsi Kognitif pada Pasien Stroke antara Lesi Hemisfer Kanan dan Kiri di Poliklinik Saraf RSUD Embung Fatimah Kota Batam Tahun 2016, Jurnal Kedokteran STM (Sains dan Teknologi Medik), JanuariJuni 2018 16-21.

Birns, J. \& Kalra, L., 2009. Cognitive function and hypertension. Journal of Human Hypertension, 23(2): 86-96.

Brucki, S. M. D., Machado, M. F. \& Rocha, M. S. G., 2012. Comprometimento Cognitivo vascular (CCV) após acidente vascular isquêmico não embólico, em seguimento de 12 meses no Brasil. Dementia e Neuropsychologia, 6(3): 164-169.

Demarin, V., Kes, V.J., Morovic, S., \& Zavoreo, I., 2009. Evaluation of Aging vs Dementia by Means of Neurosonology. Journal of Neurological Sciences, 283(1-2): 9-12.

Fahrina, D., Sinurat, P.P., \& Rambe, A.S., 2018. Correlation between Acute Stroke and Concentration of Creatine Kinase Myocardial Band, Troponin T, Hemoglobin, and Electroyltes. Kemas (Jurnal Kesehatan Masyarakat), 14(1): 71-80.

Glader, E. L., Sjolander, M., Eriksson, M., \& Lundberg, M., 2010. Persistent use of secondary preventive drugs declines rapidly during the first 2 years after stroke. Stroke, 41(2):397-401.

Gorelick, P. B., Scuteri, A., Black, S.E., DeCarli, C., Greenberg, S.M., Ladecola, C., Launer, L.J., Laurent, S., Lopez, O.L., Nyenhuis, D., Petersen, R., Schneider, J.A., Tzourio, C., Arnett, D.K., Bennett, D.A., Chui, H.C., Higashida, R.T., Lindquist, R., Nilsson, P.M., Roman, G.C., Sellke, F.W., \& Seshadri, S., 2015. Vascular Contributions to Cognitive Impairment. Neurol., Clin. pract., 5(3): 201208.

Harsono., 2007. Kapita Selekta Neurologi. Yogyakarta: Gadjah Mada University Press.

Hanas, M., Lestari, E., \& Asni, E.K., 2014. Gambaran
Fungsi Kognitif pada Pasien Pasca Stroke di Poliklinik Saraf RSUD Arifin Achmad Provinsi Riau, JOM FK, 3(1):1-12.

Hermann, D. M., \& L., B. C. 2009. Sleep-related Breathing and Sleep-wake Disturbances in Ischemic Stroke. Neurology, 73(16): 13131322.

Irdawati., 2012. Latihan Gerak Terhadap Keseimbangan Pasien Stroke NonHemoragik. Kemas (Jurnal Kesehatan Masyarakat), 7(2): 134-141.

Kabi, G. Y. C. R., Tumewah, R., \& Kembuan, M. A. H. N., 2015. Gambaran Faktor Risiko pada Penderita Stroke Iskemik pada Usia Dewasa Muda. e-Clinic (eCI), 3(1): 1-6.

Kemenkes RI., 2013. Riskesdas 2013, Badan Penelitian dan Pengembangan Kesehatan Departemen Kesehatan Republik Indonesia. Jakarta.

Knopman, D. S., Roberts, R.O., Geda, Y.E., Boeve, B.F., Pankratz, V.S., Cha, R.H., Tangalos, E.G., and Petersen, R.C., 2011. Association of Prior Stroke with Cognitive Function and Congitive Impariment. Arch Neurology, 66(5): 614-619.

Kurniawati, H., Ikawati, Z., \& Gofir, A., 2015. Pencegahan Sekunder Untuk Menurunkan Kejadian Stroke Berulang Pada Stroke Iskemik. Jurnal Manajemen dan Pelayanan Farmasi (JMPF), 5: 19.

Martini, S., 2002. Gangguan Kognitif Pasca Stroke dan Faktor Risikonya. Med Masy, 18(4): 247.

Mellon, L., Brewer, L., Hall, P., Horgan, F., Williams, D., \& Hickey, A., 2015. Cognitive impairment six months after ischaemic stroke: A profile from the ASPIRE-S study. BMC Neurology, 15(1): 1-9.

Murtiyani, N., Hartono, A., Suidah, H., \& Pangertika, N.P., 2017. Fungsi Kognitif dengan Activities of Daily Living (ADL) pada Lansia, ejournal P2M Stikes Mojokerto, 1: 235-248.

Myers, J. S., 2008. Factors Associated with Changing Cognitive Function in Older Adults: Implications for Nursing Rehabilitation' Rehabilitation Nurse. 33(3): 117-123.

Putra, I. D. G. R. C., Pinzon, R. T., \& Pramudita, E. A., 2016. Hubungan Antara Tingkat Kepatuhan Minum Obat Antiplatelet Aspirin Dengan Kejadian Stroke Iskemik Berulang Di RS Bethesda Yogyakarta. Media Farmasi, 13(1): 49-60.

Putri, M. N., Mutiawati, E., \& Mahdani, W., 2017. Hubungan Derajat Stroke Terhadap Status Kognitif Pada Pasien Stroke Iskemik Di Poliklinik Saraf Rumah Sakit Umum Daerah 
dr. Zainoel Abidin Banda Aceh. Jurnal Ilmiah Mahasiswa Kedokteran Medisia, 2(1): 61-67.

Rahayu, S., Utomo, W., \& Utami, S., 2014. Hubungan Frekuensi Stroke Dengan Fungsi Kognitif Di RSUD Arifin Achmad. Journal of Medicine PSIK, 1 (2): 1-10.

Rahman., Dewi, F.S.T., \& Setyopranoto, I., 2017. Dukungan Keluarga dan Kualitas Hidup Penderita Stroke pada Fase Pasca Akut di Wonogiri. Berita Kedokteran Masyarakat (BKM Journal of Community Medixine and Public Health) 33(8): 383-390.

Ratnasari, D., 2010 Perbedaan Skor Fungsi Kognitif Stroke Iskemik Pertama dengan Iskemik Berulang dengan Lesi Hemisfer Kiri. Universitas Sebelas Maret.

Setiawati, A., 2013. Suatu Kajian Molekuler Ketergantungan Nikotin. Jurnal Farmasi Sains dan Komunitas, 10(2): 118-127.

Stroke Association., 2010. Stroke and The Risk of Stroke, Advanced Metallization Conference (AMC).

Sun, J. H., Tan, L., \& Yu, J., 2014. Post-stroke Cognitive Impairment: Epidemiology, Mechanisms and Management. Annals of translational medicine, 2(8): 1-16.

Suwantara, J. R., 2004. Depresi Pasca-stroke: Epidemiologi, Rehabilitasi dan Psikoterapi. Jurnal Kedokteran Trisakti, 23(4): 150-156.
Totting, S., Pinzon, R. T., \& Widiasmoko, B., 2017. ArtikelPenelitian Hubungan Diabetes Mellitus denganGangguan Fungsi Kognitif Post Stroke Iskemik di RumahSakit Bethesda, 6(3): 647-653.

Wang, Z., Veluw, S.J.V., Wong, A., Liu, W., Shi, L., Yang, J., Xiong, Y., Lau, A., Biessels, G.J., \& Mok, V.C.T., 2016. Risk Factors and Cognitive Relevance of Cortical Cerebral Microinfarcts in Patients with Ischemic Stroke or Transient Ischemic Attack. Stroke, 47(10): 2450-2455.

Wu, Y., Wang, M., Ren, M., \& Xu, W., 2013. The Effects of Educational Background on Montreal Cognitive Assessment Screening for Vascular Cognitive Impairment, No Dementia, Caused by Ischemic Stroke. Journal of Clinical Neuroscience, 20(10): 1406-1410.

Yudawijaya, A., Kustiowati, E., \& Pemayun, T. G. D., 2011. Homosistein Plasma dan Perubahan Skor Fungsi Kognitif pada Pasien Pasca Stroke Iskemik. Media Medika Indonesiana, 45(5): 194-199.

Zulkifly, M.F.M., Ghazali, S.E., Din, N.C., Singh, D.K.A., \& Subramaniam, P., 2016. A Review of Risk Factors for Cognitive Impairment in Stroke Survivors. Scientific World Journal. Hindawi Publishing Corporation, 2016. 